\title{
THE CONFLICTUAL CRAFT*
}

\author{
FELIPE G. A. MOREIRA \\ https:/ / orcid.org/0000-0002-7764-1231 \\ University of Miami \\ Department of Philosophy \\ Florida \\ United States \\ felipegustavomoreira@yahoo.com.br
}

\author{
Article info \\ CDD: 149.3 \\ Received: 27.04.2019; Accepted: 09.07.2019 \\ DOI: http://dx.doi.org/10.1590/0100-6045.2019.V42N2.FM
}

\begin{abstract}
* I would like to thank the University of Miami's Ethics and Philosophy Summer Internship program for having financed (during the Northern Hemisphere's summer of 2018) the research that ultimately led to this essay. I also would like to thank the anonymous referees of Manuscrito as well as Amanda Moreira, Berit Brogaard, Irene Olivero, Mark Rowlands, Markus Gabriel, Michael Forster and Michael Slote for valuable comments on previous versions of this article, and/or on the larger research in which this article is inserted: that of my $\mathrm{PhD}$ dissertation, Disputes: The Incommensurable Greatness of Micro-Wars (Moreira 2019), where I more carefully articulate the conflictual craft defended here in spelling out this craft's power to articulate a new kind of metametaphysical system. Among other things, this system is characterized by an interpretation of Friedrich Nietzsche's project of overcoming metaphysics vis-à-vis Rudolf Carnap's as well as by a heterodox reading of Gilles Deleuze's approach to metaphysics. Regarding these two matters, see also my own Moreira (2018) and Moreira (forthcoming), respectively. I am also especially grateful to Otávio Bueno, not only for the outstanding feedback he provided me, but also for having introduced me and guided my readings of Pyrrhonism and neoPyrrhonism. Ultimately, this article is my attempt to respond to Bueno's Pyrrhonist challenges.
\end{abstract}




\author{
Keywords \\ Skepticism \\ Dogmatism \\ Neo-Pyrrhonism \\ Conflict \\ Disputes
}

\begin{abstract}
Are contemporary philosophers to follow Pyrrho of Elis in adopting his skeptic craft or at least core aspects of it as a reaction to the fact that, since immemorial times, persons have been engaged in disputes in metaphysics? Over the last 2500 years or so, most Western philosophers have not done so in being more influenced by Aristotle's dogmatic craft than by Pyrrho's skeptic one. Over the last fifty years or so, a few Brazilian neo-Pyrrhonist philosophers, such as Oswald Porchat, Otávio Bueno and Plínio Junqueira Smith, have done the opposite in aiming to spell out the pertinence of Ancient Pyrrhonism to contemporary philosophy. On its part, this essay makes a case for the claim that one is to react to the stated fact by adopting a conflictual craft that promotes a synthesis of Pyrrho's skeptic craft and the dogmatic craft. This synthesis: brings to light the core features of the skeptic and of the dogmatic craft; problematizes the dogmatic craft by means of the skeptic one and vice-versa so that the shortcomings of these crafts are avoided; and aims to keep certain positive aspects both of the skeptic craft and of the dogmatic one.
\end{abstract}

\title{
INTRODUCTION
}

"Bare wise persons". This expression may be used to translate the Greek word, "gumnosophistai". ${ }^{1}$ This word was

1 This Greek word has been, traditionally, translated to "naked wise men". However, I wish to rely on a more gender-neutral vocabulary. This is why I replace the term "men" for "persons". I also prefer the term "bare" over the term "naked". The reason is that "bare" hopefully reminds readers of the expression, "bare particular". A bare particular has been understood as a substance 
employed by Diogenes Laertius in his third century CE Lives of Eminent Philosophers. ${ }^{2}$ This work states that Pyrrho of Elis, who is believed to have lived from 365-360 BC until around 275-270 BC, joined the conqueror Alexander the Great in an expedition to India. This probably occurred around 327-326 BC. According to Diogenes, it was then that, after Pyrrho encountered such "bare wise persons", he became a skeptic. Pyrrho left no writings. His interpreters, then, have relied heavily on secondary sources, such as Diogenes's Lives of Eminent Philosophers itself as well as on the most detailed of these sources: a work by Sextus Empiricus written sometime around the second and the third century CE, Outlines of Skepticism. ${ }^{3}$

Given that non-Pyrrhonist kinds of skepticism will not be addressed in this essay, the term "skeptic" is applied as a short for the Pyrrhonist skeptic, the one who adopts Pyrrho's skeptic craft as opposed to a dogmatic craft, such as Aristotle's. As it is well-know, Aristotle was a dogmatist who is believed to have lived from 384-322 BC, worked as teacher of Alexander and was a contemporary of Pyrrho. ${ }^{4}$

that merely instantiates universals but, in itself, has no property of its own. A bare wise person, on the other hand, is one that, when stripped from one's clothes or any other cultural features, such as earrings and necklaces, still has the property of being a person.

${ }^{2}$ More precisely, this term can be found in the opening paragraph of Diogenes's account of Pyrrho at Book IX, chapter 11, \$61. See Diogenes Laertius (2018).

${ }^{3}$ Sextus Empiricus (2000). Henceforth, this work will be quoted as: (PH Roman Number of the Book and Number of the Paragraph).

4 I am inclined to believe that Aristotle is, indeed, the first Western dogmatist whose writings are available to us. Given that Plato's works are dialogues, I am not inclined to attribute to him the dogmatic craft. I am also not inclined to believe that Plato adopted a skeptic or the conflictual craft that I describe and 
"Craft" is a term used here in the Greek sense of techne, a conjunction of disciplined practices. By a practice, it is to be understood what Sextus calls a "persuasion", that is, "a choice of life or of a way of acting practiced by one person or by many". ${ }^{5}$ Note that the skeptic and the dogmatic craft are ways of dealing with disputes. "Disputes" is used in this essay as an umbrella term that covers two kinds of disputes that may be associated with "metaphysics": theoretical disputes regarding statements (e.g., there is evil, there is a thing-in-itself and there is consciousness), and practical disputes regarding practices (e.g., that of addressing the theoretical dispute over the existence of consciousness as opposed to those over evil and over a thing-in-itself). ${ }^{6}$ Also note that, since immemorial times, disputes have occurred among persons. "Person" is a term that will be applied here in the sense of someone or something that has what the Greeks called logos, that is, reason, logic and/or language. This essay is neutral on whether there are non-human beings, such as animals, that are also persons. ${ }^{7}$ It will also be presupposed that a person is a legitimate rational peer or

support in what follows. Plato seems to have had a quite unique craft of his own that, despise the countless commentaries of his works, has not been as influential as Aristotle's. An upfront evidence for this last claim is the fact that philosophers have not usually articulated dialogues. In fact, this form of writing is usually not even regarded as being "properly philosophical" today. I cannot discuss Plato's works here. For such an inquiry, see, for example, Muniz (2011).

5 PH I 145.

6 "Metaphysics" is used loosely here. Note, though, that this term is a quite equivocal one, as I discuss in more detail in Moreira (2018, 2019).

${ }^{7}$ For a discussion of this matter, see White (2007) and Rowlands (2019). 
at least a potential legitimate rational peer regarding disputes.

Whether Pyrrho's encounter with the aforementioned "bare wise persons" is a fact is not an issue that will be approached here. What is important is to presuppose and add another factor to Diogenes's account of Pyrrho; a factor that cannot be explicitly found in Diogenes's writings, but I take to be a plausible speculation. The factor is that, after encountering such "bare wise persons", Pyrrho adopted the skeptic craft because it appeared to him that:

(i) Among the others, some are legitimate rational peers insofar as disputes are at stake —assuming that "other" is a relational notion according to which $\mathrm{y}$ is an other with regard to $\mathrm{x}$ if, and only if: $\mathrm{x}$ and $\mathrm{y}$ are both persons who disagree regarding at least one dispute, and y's sensibility regarding this dispute is radically distinct from x's inasmuch as $y$ challenges x's logos in rejecting x's presuppositions and/or ignoring, violating or interpreting x's criterion to deal with the dispute at stake differently. ${ }^{8}$

(ii) No person has settled a dispute once and for all, that is, in a way that others could not rationally unsettle.

(iii) (i) and (ii) are extremely important points insofar as those who fail to acknowledge them react in a quite unpersuasive manner to the fact that, since

8 In my poems, I believe that I have more or less explicitly attempted to point to this view. See my collection of poems, Por uma estética do constrangimento (Moreira (2013)), as well as Moreira (forthcoming), where I discuss the differences between the modernist and the metamodernist ways of doing so.

Manuscrito - Rev. Int. Fil. Campinas, v. 42, n. 2, pp. 47-83, Abr.-Jun. 2019. 
immemorial times, persons have been engaged in disputes. ${ }^{9}$

To point toward (i) is no trivial move. Consider Alexander and members of his troops. When confronted with those that Diogenes describes as "bare wise persons", they might have believed that such persons were not exactly "persons" or "wise". This is to state that, from the perspective of most Greeks, these beings might have fallen short of personhood. This is because such beings: did not believe in the Greek Gods; never read Homeric poems; lived under political systems quite distinct from those adopted in Ancient Greece; dressed themselves with nonGreek vestments or did not dress themselves at all; had a color of skin distinct from that of most Greeks; etc. Indeed, the sounds emitted by such beings who did not speak Ancient Greek may not have been taken as evidence that they had a (non-Greek) language of their own. Therefore, it is plausible to imagine that Alexander and/or members of his troops may have labelled them barbarians. To do so is to reject (i) in suggesting that these "bare wise persons" are ultimately uncivilized and, consequently, not really legitimate rational peers concerning disputes.

9 In an article from 1802, Hegel attributes to skeptics a acknowledgment of points somehow similar to (i), (ii) and (iii) in arguing as follows: "what counts for the race as absolutely One and the same, and as fixed, eternal and everywhere constituted in the same way, time wrenches away from it; most commonly [what does this is] the increasing range of acquaintance with alien // peoples under the pressure of natural necessity; as, for example, becoming acquainted with a new continent, had this skeptical effect upon the dogmatic common sense of the Europeans down to that time, and upon their indubitable certainty about a mass of concepts concerning right and truth". See Hegel (2000: 333). For a detailed take on Hegel's view on skepticism, see Forster (1989). 
To point toward (ii) is also no trivial move. In not taking their others to be legitimate rational peers on disputes, Alexander and/or members of his troops might have also believed that at least one dispute has indeed been settled once and for all. The same can be stated about some Ancient Greeks who never joined expeditions to nonGreek cities. Note that such Greeks may also have been inclined to believe that (i) and (ii) were unimportant matters. The reason, they might have believed, is that one can, indeed, react in a persuasive way to the fact that, since immemorial times, persons have been engaged in disputes, without taking (i) and (ii) into account by, say, simply embracing a criterion to deal with a dispute as if such a criterion were universally shared. So, the action of pointing toward (iii) is also no trivial action but, rather, a quite controversial one.

But, to put it in more informal terms, what about us, contemporary philosophers? Are we to follow Pyrrho in adopting his skeptic craft or at least core aspects of it as a reaction to the fact that, since immemorial times, persons have been engaged in disputes? Over the last 2500 years or so, most Western philosophers have not done so in being more influenced by Aristotle's dogmatic craft than by Pyrrho's skeptic one. Over the last fifty years or so, a few Brazilian philosophers have done the opposite in seeking to spell out the pertinence of Ancient Pyrrhonism to contemporary philosophy. Such Brazilian philosophers are exceptions. They may be called neo-Pyrrhonists. Oswald Porchat, whose first works were published in the late 1960 s, is an example of someone who deserves to be labelled so. ${ }^{10}$ The same can be stated about the following two contemporary philosophers considerably influenced by

\footnotetext{
${ }^{10}$ Porchat (2007).
} 
him: Otávio Bueno and Plínio Junqueira Smith. ${ }^{11}$ As it will become explicit in what follows, I am quite influenced by neo-Pyrrhonists insofar as I likewise take the dogmatic craft to be a ultimately non-starter that problematically casts doubt on (i), (ii) and (iii). This essay's aim, though, is not that of addressing the works of neo-Pyrrhonists in detail, or to spell out my agreements and disagreements with them.

While further spelling out reasons for (i), (ii) and (iii), what I aim to do in this essay is a case for the claim that one is to react to the fact that, since immemorial times, persons have been engaged in disputes by adopting what may be called a conflictual craft. This craft seeks to promote a synthesis of the skeptic and of the dogmatic craft. By a synthesis between the latter crafts, it is to be understood a task characterized by three features: first, instead of presupposing, this synthesis brings to light the core features of the skeptic craft and of the dogmatic craft; second, this synthesis problematizes the dogmatic craft by means of the skeptic one and vice-versa so that the shortcomings of these crafts are avoided; and, third, this synthesis still seeks to keep certain positive aspects both of the skeptic craft and of the dogmatic one. ${ }^{12}$ Note that I do not wish to suggest that the skeptic and the dogmatic craft

${ }^{11}$ Bueno (2005, 2011, 2013); Bueno and Smith (2016); and Smith (2017). Other non-Brazilian philosophers whose works have also been influenced by Pyrrho include: Olaso (1977, 1978, 1980a, 1980b, 1983, 1999) as well as Fogelin (1994). Also consider Bueno (2016), where he discusses Rudolf Carnap's neutralism in a quite skeptic vein. For my own views on Carnap, see Moreira (2014, 2018, 2019).

12 "Synthesis" is a term that is often associated with Hegel's works. In using it in the stated sense, though, I do not wish to suggest that I champion a Hegelian approach. To spell out my agreements and disagreements with Hegel in another task that I cannot pursue in this essay. 
are the only two crafts present in the literature. Indeed, there may be other crafts that resist being labelled "skeptic" or "dogmatic" ones. Yet, I cannot address these crafts here. What I aim to do is to show that the conflictual craft is a synthesis and an alternative to the skeptic and to the dogmatic craft by: in section 1, presenting the core features of the skeptic craft and of the dogmatic craft; in section 2, problematizing the dogmatic craft by means of the skeptic one and vice-versa; and, finally, in section 3, spelling out the conflictual craft.

\section{The Skeptic Craft and the Dogmatic Craft}

The skeptic acknowledges that, since immemorial times, persons have been engaged in disputes. The dogmatist also acknowledges so. Consider Aristotle. In the first book of his Metaphysics as well as in the first book of his De Anima, he addresses several aporiai, that is, logical stalemates that seem to make a question ultimately unanswerable. In doing so, Aristotle also acknowledges that, since immemorial times, persons have been engaged in disputes. Yet, the dogmatic way of reacting to this fact is radically distinct from the skeptic one in at least five senses.

\section{a. Appearances vs. Beliefs}

The first sense in which the skeptic craft and the dogmatic craft are radically distinct from one another is that the skeptic craft is an ongoing investigation into the issues that have given rise to disputes. Skeptics, Sextus states, are simply "still investigating" these issues. ${ }^{13}$ The skeptic investigation, then, has no predicable end. Moreover, it

${ }^{13}$ PH I 3

Manuscrito - Rev. Int. Fil. Campinas, v. 42, n. 2, pp. 47-83, Abr.-Jun. 2019. 
only bases itself on appearances. On the other hand, the dogmatic craft is an inquiry that purports to have reached the end of an investigation. In other words, the dogmatic craft, as its name indicates, is that of dogmatists; those who "in the proper sense of the word think that they have discovered the truth" about at least one issue that gave rise to at least one dispute. ${ }^{14}$ In doing so, dogmatists do not merely live in accordance with appearances. Rather, they also commit themselves to dogmas, that is, beliefs.

Note that the terms "appearances" and "beliefs" were italicized. I did so because it is crucial to underline that, being a skeptic, Sextus does not have a theory that precisely spells out how these two terms are to be understood, that is, he does not spell out necessary or sufficient conditions for appearance and for belief, let alone for truth. Instead, he applies the terms "appearance" and "belief" in a quite loose (if not extremely vague) way. It follows that it is not surprising that Sextus' writings themselves have given rise to an exegetical dispute that has been going on for several centuries: the dispute on how the appearance/belief distinct is to be read in the first place.

As Michael Forster spells out, some of Sextus' readers are "urbane", to use Jonathan Barnes's expression. 15 These readers of the likes of Kant and, more recently, Michael Frede interpret that by a belief, Sextus only means "reasonbased beliefs concerning the supersensible", such as the beliefs that there is a beginning of the world, an immaterial soul or a God. ${ }^{16}$ Consider Pyrrho's encounter with the aforementioned "bare wise persons". Imagine that exclusively based on his senses (e.g., those of sight, hearing, taste, smell and touching), Pyrrho recognized that they were

\footnotetext{
${ }^{14}$ Ibid.

${ }^{15}$ Barnes (1997: 61).

${ }^{16}$ Forster (2005: 53). Also see Forster (2008), and Frede (1997).
} 
persons. An urbane reader might argue that, for Sextus, Pyrrho's recognition does not count as belief, but as an appearance. This reader might also claim that (i), (ii) and (iii) are appearances exclusively based on sensible experience; not beliefs. Thus, the skeptic may embrace them.

On the other hand, as Forster also indicates, there are also those, like himself, Georg Wilhelm Friedrich Hegel and Myles Burnyeat, who interpret that by a belief, Sextus means any kind of belief whatsoever. ${ }^{17}$ Barnes labels these readers, among which Barnes himself is also to be included, "rustic" readers. ${ }^{18}$ According to the rustic reading, skeptics would not commit themselves to even widely shared sensebased beliefs on the sensible. Note that such beliefs are not very easily distinguishable from appearances. Also note that rustic readers may take that Pyrrho's recognition that some "bare wise persons" are persons as a belief; not as an appearance. From the perspective of these rustic readers, the same would be the case with (i), (ii) and (iii),

It is likewise worth mentioning that there have been readers who have problematized the widely shared urbane/rustic distinction proposed by Barnes. Ultimately, these readers endorse a distinct formulation of the exegetical dispute on how Sextus' distinction between appearance and belief is to be read. Consider, for instance, Gail Fine. ${ }^{19}$ She argues that what is at stake in the stated exegetical dispute are two distinct possible readings that are not precisely captured by Barnes' distinction: the "somebelief view" interpretation and the "no-belief view" one. ${ }^{20}$

${ }^{17}$ See Burnyeat (2012).

${ }^{18}$ Barnes (1997: 61).

${ }^{19}$ Fine (1996)

${ }^{20}$ Fine (1996: 284). 
As its name indicates, those who adopt the former reading take that skeptics can embrace some beliefs. The somebelief view readers, then, have the burden of spelling out the beliefs skeptics can endorse.

For instance, it may be argued that skeptics can embrace sense-based beliefs, such as the one that the aforementioned "bare wise persons" are persons, and the beliefs that (i), (ii) and (iii). It could also be interpreted that skeptics exclusively embrace, not sense-based beliefs in general, but beliefs about their own affections, that is, beliefs about the "feelings forced upon them by appearances", such as the belief that it seems to oneself that such "bare wise persons" are persons and that (i), (ii) and (iii). ${ }^{21}$ "We [skeptics]", Sextus claims in arguably pointing to this direction, "report descriptively on each item according to how it appears to us at the time". ${ }^{22}$ This last passage may also be read as evidence that skeptics can endorse any belief whatsoever as long as such belief is not identified with a supposedly objective truth of the matter regarding the dispute at stake.

Another way to put this is by stating that the skeptic can have a belief as long as a (so to speak) it seems to me operator is placed before it. What may, arguably, back up this interpretation is the fact that, as indicated above, skeptics are those who are always "still investigating" the issues that have given rise to disputes. So, it may be argued that skeptics cannot be committed to a belief that purports to be a truth able to end the investigation at stake. "It seems to $m e$ ", a skeptic could state in this reading, that such "bare wise persons" are persons, and that (i), (ii) and (iii).

In contrast, the readers who accept the no-belief view described by Fine have a quite distinct burden: that of

\footnotetext{
21 PH I 13.

22 PH I 4.
} 
replying to the most traditional objection to the skeptic craft according to which this craft self-refutes itself insofar as its adherents propose but fail to live without having any belief whatsoever. This objection will be further discussed in what follows. Before I do so, it is important to underline that this essay likewise does not aim to carefully address (let alone, solve) the exegetical dispute on how Sextus' distinction between appearance and belief is to be read. As the last six paragraphs indicate, this is an extremely complex interpretative dispute. Hence, in order to carefully address it, a whole new essay focused on Sextus' exegesis would have to be written.

What I would like to do, instead, is to limit myself to not use the term and remain neutral on "truth", while proposing a plausible reading of the appearance/belief distinction. While doing so, I do not wish to commit myself to any strong exegetical point, such as that this plausible reading of mine is more persuasive than other ones present in the extremely extensive literature on Sextus' works. The reading I propose is that, for Sextus, an appearance is distinct from a belief insofar as: an appearance is less controversial and, consequently, less likely to give rise to a dispute than a belief.

Textual evidence points to this reading of mine. What I mean is that it is plausive to interpret that Sextus takes an appearance to be less controversial and, hence, less likely to give rise to a dispute than a belief because he states that an appearance is "equally apparent to everyone and agreed upon and not disputed". ${ }^{23}$ On the other hand, Sextus states that belief "is assent to some unclear object of investigation in the sciences". ${ }^{24} \mathrm{I}$ read, then, that Sextus takes belief to be quite controversial and, so, more likely to give rise to a

\footnotetext{
${ }^{23}$ PH II 8.

${ }^{24}$ PH I 13.
} 
dispute than an appearance. It is important to emphasize that Sextus states that "disputed items, insofar as they have been subject to dispute, are unclear" and "on everything unclear there has been an interminable dispute". ${ }^{25}$ Furthermore, consider that Sextus suggests that disputes occur when everyday life is disrupted and "opposed accounts" are held. ${ }^{26}$

In contrast, then, Sextus describes skeptics as those who live in accordance with appearances insofar as they "set out without opinions [doxai] from the observance of ordinary life", that is, skeptics "live in accordance with everyday observances". ${ }^{27}$ There are four kinds of such everyday observances. The first everyday observance is "guidance by nature". ${ }^{28}$ This is the power to perceive appearances and to think about appearances. Now consider someone seeking to satisfy one's needs for food and drink. To do so is to act in accordance with a "necessitation by feelings". ${ }^{29}$ This is the second everyday observance. The third everyday observance is the "handing down of laws and customs".30 This is the power to grasp the widely shared norms of one's community, such as the norm that "piety is good and impiety bad". ${ }^{31}$ The fourth everyday observance is the "teaching of kinds of expertise", such as that of playing a musical instrument. ${ }^{32}$

${ }_{25}$ PH II 182 and PH II 8, respectively.

${ }^{26} \mathrm{PH} \mathrm{I} 4$.

27 PH II 254 and PH I 23, respectively.

28 PH I 23.

29 Ibid.

30 Ibid.

31 Ibid.

32 Ibid.

Manuscrito - Rev. Int. Fil. Campinas, v. 42, n. 2, pp. 47-83, Abr.-Jun. 2019. 
I also would like to assume that the appearance/belief distinction is sensitive to context, even though Sextus does not explicitly state so. The reason I make this move is that, given my stated interpretation of this distinction, it is quite plausible to take this distinction to be sensitive to context. Consider, once again, Pyrrho's encounter with the aforementioned "bare wise persons". In most contexts of everyday life, the statement that the latter are persons is a non-controversial "clear" appearance; one that is held by someone who is guided by nature. The same can be stated about (i), (ii) and (iii). In other more dogmatic contexts, though, these three points themselves may count as beliefs. This is because they may raise a theoretical dispute between the one who endorses them and an opponent who believes that such "bare wise persons" are not persons, and that (i), (ii) and (iii) are to be rejected. Note that this opponent could go as far as problematizing the very criterion that allows one to conclude that some "bare wise persons" are persons, say, this opponent may argue that accordance with one's sensible experience is not the criterion that is to be adopted in spelling out whether these "bare wise persons" are persons. This is because one's senses are not always reliable, that is, a being could appear to be a person and still be something else that falls short of logos. Moreover, this opponent may also claim that it is not at all clear that sensible experience is enough to back up (i), (ii) and (iii); that another criterion is to be adopted to do so.

This is to state that one person's appearance is another person's belief (and vice-versa). ${ }^{33}$ Henceforth, then, the

33 Note that Sextus was inserted in a context in which most people were pious in taking the Greek gods to exist, and to be provident. Hence, the norm that one is to be pious counted for him as an appearance, that is, as a way of handing down a custom. Sextus indicates so in stating that in "following ordinary life without opinions, we [skeptics] say that there are gods and we 
(much less philosophical loaded) term "claim" will be technically used to refer to that which resists been qualified as an appearance or as a belief, that is, that which may be an appearance in certain contexts, but a belief in others. Given that most beliefs count as appearances in certain contexts and vice-versa, I will mainly speak in terms of "claims" in what follows. Accordingly, I would like to describe (i), (ii) and (iii) as claims; not as appearances or as beliefs. Moreover, my proposed reading is that skeptics may merely insinuate, indicate or point toward without never explicitly making a case or explicitly embracing (i), (ii) and (iii). The reason is that there are dogmatic contexts in which (i), (ii) and (iii) are beliefs that lead to disputes.

\section{b. Undecidability and Strong Decision}

The second sense in which the skeptic craft and the dogmatic craft are radically distinct from one another is that those who adopt the former craft seek to spell out that disputes have seemed to be anepikritos, that is, undecidable. Note that to seek to spell out so is not to be confounded with the attitude of stating that is "true" that disputes are undecidable. Sextus calls those who make this move "Academics", not skeptics. ${ }^{34}$ I will not address the academic craft here. For my purposes, what is crucial, instead, is to emphasize that dogmatists, on the other hand, believe that at least one dispute is decidable once and for all. In doing so, they suggest that their own works attest to the existence of at least one undeniable metaphysical claim, that is, a claim that may be associated with "metaphysics" (broadly

are pious towards the gods and say that they are provident". See PH III 2.

${ }^{34}$ PH I 3.

Manuscrito - Rev. Int. Fil. Campinas, v. 42, n. 2, pp. 47-83, Abr.-Jun. 2019. 
constructed), and that each and every person is to endorse in order to count as a legitimate rational peer concerning a dispute at stake. To suggest so, then, is to indicate that a strong decision regarding at least one dispute is attainable.

\section{c. Equipollence and Strong Non-Equipollence}

The third sense in which the skeptic craft and the dogmatic craft are radically distinct from one another is that, given any dispute whatsoever, skeptics also aim to spell out that it appears to exist an isostheneia, that is, an equipollence regarding the claims or practices of the conflicting parties. This is to state that skeptics aim to spell out that such conflicting parties ultimately have equally rationally persuasive views. Dogmatists, on the other hand, argue that there are strong ways of avoiding the equipollency of their own claims or practices with those of their opponents. For dogmatists, this could be done by showing that, regardless of context, their claims are more rationally persuasive than their opponents'. This is because, for dogmatists, undeniable metaphysical claims would be justified by one or a conjunction of first principles or starting points.

By a starting point, it is to be understood a "selfevident" likewise undeniable metaphysical claim or criterion to deal with the dispute at stake that no person may rationally reject and that ultimately justifies all other claims and practices endorsed by the dogmatist. The dogmatist who endorses a single starting point may be called foundationalist dogmatist. I call coherentist dogmatist the dogmatist who embraces a conjunction of such starting points. On his part, Sextus states that skeptics aim to be "philanthropic" regarding dogmatists; this is to state that 
skeptic "wish to cure by argument, as far as they can, the conceit and rashness of the Dogmatists". 35

The dogmatist' conceit and rashness are those of taking oneself to be able to provide an undeniable metaphysical claim, even though no such claim appears attainable. The philanthropic skeptic cure is pursued by means of a tropos, that is, a mode. Sextus spells out fifteen of such modes. He attributes ten of these modes to the "older skeptics"; he attributes five modes to "the more recent Skeptics". ${ }^{36}$ The latter modes, Diogenes states, are those of "Agrippa and his school". ${ }^{37}$ I will briefly comment on the tenth mode of the older skeptics in what follows. Nevertheless, the modes of Agrippa have been traditionally understood as being the most challenging for dogmatists. This is why I would like to primarily focus on them in this essay.

The first mode of Agrippa is that of dispute; it is to suggest that it appears that any theoretical dispute at stake is an undecidable one in that claims about it that contradict or run in tension with one another have been held. Indeed, there have been contrasting claims even about what is a belief; what is an appearance; etc. Agrippa's second mode is infinite regress. This mode indicates that that which is supposed to justify one's claim about a theoretical dispute (e.g., a criterion to deal with a dispute) is itself in need of further justification, and so on ad infinitum.

The third mode of Agrippa may be called relativity. This mode serves to indicate that one's criterion to address the theoretical dispute at stake is not universally shared, but relative to one's own culture. This is why others may rationally reject this criterion. Agrippa's fourth mode is

${ }^{35}$ PH III 280.

36 PH I 36 and PH I 164, respectively.

37 The passage can be found in Diogenes's account of Pyrrho at Book IX, chapter 11, §88. See Diogenes Laertius (2018). 
hypothesis. This mode aims to show that, in order to avoid the infinite regress, one needs to ask one's opponents for a concession "without proof" of a hypothesis, say, a criterion to deal with the theoretical dispute at stake. ${ }^{38}$ The fifth mode of Agrippa is circularity: to show that, in order to avoid asking for a concession, one may ultimately presuppose the very claim or the criterion to back up the claim that is been theoretically disputed. In relying on such modes, skeptics seek to insinuate that dogmatists are "sick" in taking their claims to be undeniable metaphysical ones.

\section{d. Suspension of Judgment and Universal Judgment}

The fourth sense in which the skeptic craft and the dogmatic craft are radically distinct from one another is that skeptics seek to bring about at least in themselves an epochè, that is, a suspension of judgment. On their parts, dogmatists do not do so. Rather, what dogmatists do is to commit themselves to undeniable metaphysical claims. In other words, they make supposedly universal judgments. Now let me underline that to bring (at least in oneself) a suspension of judgment is not to be committed to the normative claim that one should do so. Instead, it is to not commit oneself to any claim whatsoever, including the very claim that one is to suspend judgment.

\section{e. Tranquility and Fundamental Health}

The fifth sense in which the skeptic craft and the dogmatic craft are radically distinct from one another concerns what these crafts aim to achieve. Ultimately, skeptics seek to experience an ataraxia. This is a feeling of

${ }^{38}$ PH I 168.

Manuscrito - Rev. Int. Fil. Campinas, v. 42, n. 2, pp. 47-83, Abr.-Jun. 2019. 
tranquility, that is, "a freedom from disturbance or calmness of soul"; one that, skeptics insinuate, would arise after one suspends judgment. ${ }^{39}$ On theirs parts, dogmatists seek to achieve something quite different: they ultimately aim to experience what may be called a fundamental health. By this kind of health, it is to be understood that of rationally thinking in accordance with what all persons insofar as holders of logos think, act or should think and act.

\section{Problematizing the Dogmatic and the SKEPTIC CRAFT}

Let us now problematize the dogmatic craft by means of the skeptic craft, and vice-versa so that the shortcomings of these crafts become explicit and, hence, may be avoided.

\section{a. Against the Dogmatic Craft}

To problematize the dogmatic craft by means of the skeptic craft is to follow skeptics in stating, to speak like them, that "it seems to me" that dogmatists ultimately suffer from the stated "conceit and rashness" identified by Sextus: the "conceit and rashness" of taking oneself to be able to provide at least one undeniable metaphysical claim, even though no such claim appears attainable. ${ }^{40}$ Notice that what points toward this objection to dogmatists is the very acknowledgment of (i), (ii) and (iii). To begin with, consider

$39 \mathrm{PH}$ I 10. Moreover, note that the interpretation of the skeptic craft proposed here is quite influenced by Burnyeat's reading. As he states, this craft's "sequence is: conflict - undecidability equal strength - epoché, and finally ataraxia". See Burnyeat (2012: 209).

40 PH III 280.

Manuscrito - Rev. Int. Fil. Campinas, v. 42, n. 2, pp. 47-83, Abr.-Jun. 2019. 
that if, as (i) indicates, some others (who sometimes are other dogmatists) are legitimate rational peers insofar as disputes are at stake, it is hard to understand how dogmatists can obtain any undeniable metaphysical claim, that is, it seems that some others can and have actually constantly rationally rejected any allegedly undeniable metaphysical claim proposed by dogmatists. Indeed, the skeptic appeal to the aforementioned modes also points to this direction.

Moreover, if, as (ii) indicates, no person has settled a dispute once and for all, dogmatists seem to be, indeed, "conceited". This is because they suggest that their own works attest to otherwise, while ignoring that the history of metaphysics itself seems to be the history of disputes that have not been solved once and for all. Third, it seems that dogmatists could only take themselves to be able to obtain at least one undeniable metaphysical claim if they "rashly" ignore (i) and (ii), say, by acting as if they did not have any others and, so, were able to solve disputes once and for all, say, by naively appealing to a criterion to deal with disputes (e.g., accordance with intuitions) as if such a criterion were universally shared. This appeal, though, seems unpersuasive, given that (i) and (ii) are, if not appearances, at least widely shared claims.

Like skeptics, then, I am not convinced that dogmatists have been able to discover a truth of the matter or to attain a strong decision concerning disputes. I am not convinced that dogmatists are able to strongly avoid the equipollence of their views with that of their opponents, such as their others. I am also skeptical about the possibility of universal judgments, and that of reaching the dogmatic goal of achieving the aforementioned universal health. It seems that persons cannot obtain this health because their others are always problematizing logos or what one takes to be so. 


\section{b. Against the Skeptic Craft}

I likewise wish to problematize the skeptic craft by means of the dogmatic one. Nevertheless, I do not wish to do so in the most traditional way, that is, by embracing the stated traditional objection to the skeptic craft according to which this craft self-refutes itself insofar as its adherents propose but fail to live without having any belief. Notice that this objection can be found in Diogenes's Lives of Eminent Philosophers itself and was more recently rearticulated by Burnyeat. ${ }^{41}$ It is not this essay's aim to discuss this objection in detail. Yet, I emphasize that this objection depends on a reading of the appearance / belief distinction insofar as those who endorse it suggest that belief involves an active volition to endorse one practice over another one. This essay is neutral on whether belief is to be characterized so, but a few points are likewise to be considered: the appearance / belief distinction, as indicated above, is not precisely made by Sextus; this essay has used the term "belief" in the stated sense of something "unclear" that leads to a theoretical dispute; and the problematic claim that belief also involves an active volition is one that leads to a theoretical dispute that skeptics may approach by means of the skeptic craft.

What will be presupposed, then, is that skeptics may live free of belief. They may do so by, on the one hand, endorsing what they take to be "clear" and uncontroversial appearances whenever they are inserted in everyday life contexts. On the other hand, they may adopt the skeptic craft in suspending judgment and not committing themselves to any "unclear" and controversial belief when they are within more dogmatic contexts of theoretical

${ }^{41}$ This objection can be found at Book IX, chapter 11, \$102-105 of Diogenes's account of Pyrrho. See Diogenes Laertius (2018). Also consider Burnyeat (2012: 205). 
disputes. What skeptics cannot do, as Sextus himself acknowledges, is to live over and above appearances, that is, they need to embrace the four kinds of everyday observances. In doing so, skeptics cannot be neutral regarding practices, that is, they need to do something in taking one course of action instead of another one.

Notice that Sextus himself acknowledges that skeptics cannot be practically neutral; skeptics "are not able to be utterly inactive", he recognizes. ${ }^{42}$ Indeed, the impossibility of practical neutrality is an appearance in most contexts. What Sextus does not acknowledge, though, is that the skeptic craft can be problematized by means of the dogmatic one, not by endorsing the stated traditional objection, but by pointing toward a properly skeptic kind of "conceit and rashness": the conceit and rashness of apparently wishing to achieve an ultimately impossible neutrality regarding practices, while engaging oneself in the exclusively negative skeptical investigation and failing to positively explicitly justify the practices that oneself inevitably actively endorses. Let me carefully spell out what I mean by this alternative objection so that it becomes explicit that, ultimately, the skeptic conceit and rashness are just as problematic as those of the dogmatist.

Consider Sextus' discussion of the tenth mode of the old skeptics. This mode is quite similar to Agrippa's relativity mode; it is that of opposing contrasting "persuasions and customs and laws and beliefs in myths and dogmatic suppositions" to one another. ${ }^{43}$ For my purposes, it suffices to focus on Sextus' discussion of custom, which he understands as "a common acceptance by a number of people of a certain way of acting,

\footnotetext{
42 PH I 23.
}

${ }^{43}$ PH I 145.

Manuscrito - Rev. Int. Fil. Campinas, v. 42, n. 2, pp. 47-83, Abr.-Jun. 2019. 
transgressors of which are not necessarily punished". ${ }^{44}$ Note that Sextus limits himself to "oppose custom to custom". His way of doing so is to stress that: "some of the Ethiopians tattoo their babies, while we do not; the Persians deem it becoming to wear brightly-coloured fulllength dresses, while we deem it unbecoming; Indians have sex with women in public, while most other people hold that it is shameful" ".5 My reading is that Sextus' discussion of such customs is evidence of the alternative objection.

To begin with, in endorsing the merely negative skeptic investigation, Sextus seems to wish to achieve an ultimately impossible neutrality regarding practices. This is so insofar as he simply does not care to spell out what he would do in a context in which he actually had to decide between accepting or rejecting the stated customs, that is, Sextus does not discuss whether he actively endorses the practices of tattooing a baby, wearing brightly-coloured full-length dresses or having sex with women in public. As if he could remain practically neutral regarding these practices and/or all other practices, what Sextus limits to do is to attempt to bring about at least in himself a suspension of judgment that would cause tranquility, that is, he indicates that to endorse or to not endorse the stated customs are equally rationally persuasive courses of actions. However, as Sextus acknowledges, skeptics "are not able to be utterly inactive". ${ }^{46}$ Hence, skeptics, like everybody else, need to endorse practices. I object, then, that the skeptic craft simply fails to positively explicitly justify the practices that skeptics inevitably endorse in the end, such as the very practices of tattooing or not tattooing a baby; wearing or not wearing brightly-coloured full-length dresses; having or

\footnotetext{
44 PH I 146.

45 PH I 148.

46 PH I 23.
} 
not having sex with women in public; etc. Hence, a skeptic's decision of adopting a practice as opposed to any other one is a barely justified decision. Arguably, this decision may be even an arbitrary one. Let us consider two other examples that point to this direction.

First, imagine that Pyrrho was next to Alexander when the latter's troops were positioned to fight those of the Indians. Imagine that, in relying on the skeptic craft and seeking to achieve tranquility, Pyrrho suspended judgment on whether this fight is to be held, that is, Pyrrho felt that to fight or not to fight the Indians were equally rationally persuasive courses of action so that no strong decision for one course of action or the other could be obtained. Yet, Pyrrho still had to act, say, by joining Alexander's troops; trying to stop them in spelling out the skeptic craft; running away from the battle; remaining paralyzed; crying in desperation; etc. I object, then, that in relying on the skeptic craft and apparently wishing to achieve an impossible neutrality concerning all of these practices, Pyrrho would fail to positively explicitly justify whatever practice he actively endorsed in the end. The reason is that, in order to justify such a practice, Pyrrho would have to commit himself to at least one belief or claim. This is because it seems to be an appearance that there ultimately is no non-controversial appearance that could justify the endorsement of one course of action, instead of another one. Hence, given that the skeptic craft does not allow Pyrrho to embrace beliefs or claims, his practical choice of one course of action would be a barely justified choice. Arguably, his choice could even be a considerably arbitrary choice that lacks any justification.

Second, imagine a male guard who works at the U.S. / Mexico border and turns out to be a skeptic. Imagine that this guard suspends judgment on the dispute on whether children of illegal Mexican immigrants caught in the border are to be separated from their parents. He feels that the 
decisions of separating and of not separating these children from their parents are equipollent, that is, their "levels" of rational persuasion are similar. Hence, from this guard's perspective, neither one of these decisions seems a strong one. In fact, he feels that more right-wing politicians, such as Donald Trump or Jair Bolsonaro, are just as rationally persuasive as more left-wing ones of the likes of Barack Obama or the former Brazilian president, Luis Inácio Lula da Silva. Indeed, let me underline that, as the neoPyrrhonists, Bueno and Junqueira Smith themselves, state, another neo-Pyrrhonist, "Porchat (in conversation)", goes as far as holding that "the skeptic could have any political doctrine, including a radical one: from extreme right to extreme left." 47

However, note that the imagined guard still needs to act, say, by enforcing the law that children of illegal immigrants caught in the border are to be separated from their parents; turning the blind eye on this law and not enforcing it; quitting his job; etc. My view, then, is that in relying on the skeptic craft and apparently wishing to achieve an impossible neutrality concerning all of these practices, this guard would also fail to positively justify the practice he actively ultimately endorses; his practice would also be a barely justified practice and, perhaps, even an arbitrary practice, given that no belief or claim is used to justify it. To put in the Portuguese language of neo-Pyrrhonists themselves and in terms that are widely shared in Brazil, this is to state that a skeptic seems to aim, but inevitably fail to be an "isentão", someone who takes no practical party once a dispute arises. Ultimately, skeptics simply take a barely justified or even arbitrary stance.

${ }^{47}$ Bueno and Smith (2016: 9).

Manuscrito - Rev. Int. Fil. Campinas, v. 42, n. 2, pp. 47-83, Abr.-Jun. 2019. 


\section{The Conflictual Craft}

Now, I would like to characterize the conflictual craft in contrast to the skeptic and the dogmatic one. This will serve to spell out in which sense the former craft keeps certain aspects of the latter two crafts while avoiding both the dogmatic and the skeptic conceit and rashness.

\section{a. Neither Appearances nor Beliefs but Claims}

The conflictual craft is neither a skeptic ongoing investigation exclusively based on appearances nor a dogmatic inquiry that purports to have a belief that is "true", regardless of context. Like the skeptic craft, the conflictual craft is a kind of investigation. However, a conflictual crafter is someone who acknowledges the impossibility of practical neutrality, that is, the impossibility of being an "isentão". Like the dogmatist, then, the conflictual crafter explicitly seeks to justify whatever claims and/or practices one ultimately positively endorses. In doing so, the conflictual investigation provisionally stops the investigation in settling for a claim and/or practice justified by the imperfect justificatory resources one currently has at his or her disposal.

By an imperfect justificatory resource, it is to be understood a resource that backs up a claim and/or a practice in a way that currently strikes the conflictual crafter as being persuasive, even though this might change in the future and no end of the process of justification of one's practices and claims seems predictable. In fact, this justificatory process may be one whose end is unpredictable or that is only bounded by the conflictual crafter's own 
finitude. ${ }^{48}$ This is why conflictual crafters are never completely epistemically satisfied; they never cease to attempt to justify their very own claims and practices, regardless of their very likely impossibility of convincing all of their others, or even themselves once and for all. The following are examples of imperfect justificatory resources that have been used in this very essay: to claim that basic empirical observation of the history of metaphysics backs up (i), (ii) and (iii); to argue that the above articulations of the skeptic and of the dogmatic craft are backed up by a plausible reading of Sextus' writings; etc.

Distinct from skeptics, then, I am not neutral on all claims. Indeed, I take that (i), (ii) and (iii) are more persuasive than their denials; that this essay's thesis (that one is to react to the fact that, since immemorial times, persons have been engaged in disputes by adopting what may be called a conflictual craft) is likewise more persuasive than its denial; that to avoid the dogmatic "conceit and rashness" is somehow "better" than to do otherwise; that to justify one's claims and practices is likewise somehow "better" than to aim and fail to be an isentão; etc. Note that to embrace the last phrase's claims is a quite controversial move. This is so insofar as my others are very likely to reject them, say, in suggesting that none of their others are legitimate rational peers; in taking themselves to have solved a dispute once and for all; by taking the acknowledgement of (i) and (ii) to be an ultimately irrelevant one; by claiming that one is not to adopt the conflictual craft; by arguing that there is nothing "wrong" about the dogmatic "conceit and rashness"; by suggesting that there is also nothing "wrong" about aiming and failing to be an isentão; etc.

48 There might be some resemblances between the conflictual craft, and infinist views, such as Peter Klein's. This is not an issue that can be addressed here. For infinitism, see Klein (2007). 
Distinct from skeptics, though, I do not take the fact that my others will disagree with whatever move I make, with whatever criterion I propose or with whatever claim I endorse as a reason for seeking an ultimately impossible practical neutrality. Rather, this is merely a reason for recognizing myself as (perhaps, inevitably) inserted into what may be called a conflictual community. By this community, it is to be understood one in which theoretical and practical disputes constantly take place, and for every member $\mathrm{x}$, there is another member $\mathrm{y}$ so that $\mathrm{x}$ and $\mathrm{y}$ are others of one another. The following are some examples of conflictual communities: that of all holders of logos; the Western community; the community of all contemporary philosophers; or, even more narrowly, the community of all philosophers in a certain philosophy department; etc. Notice that the fact that the conflictual craft takes for granted that persons have always been inserted into such conflictual communities is a first reason for calling this craft a conflictual craft.

\section{b. Neither Undecidability nor Strong Decision but Weak Decision}

The conflictual craft neither seeks to skeptically spell out that disputes have seemed undecidable nor purports to dogmatically achieve a strong decision concerning them, that is, one that suggests that one's own work attests to the existence of at least one undeniable metaphysical claim. Instead, the conflictual crafter is the one who takes oneself to be able to achieve a weak decision regarding disputes. This decision is one that relies on merely deniable metaphysical claims, such as (i), (ii), (iii) and this essay's thesis; claims that are backed up by imperfect justificatory resources, such as the ones mentioned in the last subsection. Another way to put this is by stating that conflictual crafters take that claims can be rationally 
supported, but not in an ultimately rationally undeniable way, as dogmatists have always wished. Note that a weak decision, then, does not lead to the ultimate end of the dispute at stake. Rather, this decision is merely one that is contextually accepted by some interlocutors but rejected by others, such as those who do not even grant that the dispute that one aims to address is a pertinent way to spend some time of one's life in the first place. What I mean, then, is that a weak decision does not purport to end conflict in convincing all persons once and for all in ending the dispute at stake. This is, accordingly, a second reason for calling the craft defended here a conflictual craft.

\section{c. Neither Equipollence nor Strong Non-Equipollence but Weak Non-Equipollence}

The conflictual craft neither seeks to skeptically spell out the equipollence of conflicting parties' claims or practices, nor purports to strongly avoid the equipollency of one's own claims and practices with those of opponents, say, by suggesting that one's own claims are, regardless of context, more persuasive than those of one's opponents. Instead, what the conflictual crafter does is to weakly avoid the equipollency of one's own claims and practices with those of one's opponents. This can be done by recognizing that the conflictual crafter's claims and practices are not immune to the skeptic modes, and that their "level" of rational persuasiveness varies with context. In other words, a conflictual crafter is someone who acknowledges that one's own claims and practices are rationally persuasive and bring consensus in certain contexts, such as those in which interlocutors share the conflictual crafter's sensibility regarding disputes; take the conflictual crafter's moves to be pertinent and even interesting; grant that the authors the conflictual crafter discusses are relevant and deserving of 
attention; do not ask for a definition of each and every term applied; do not entitle themselves to be rude with the conflictual crafter; are educated enough to understand the points the conflictual crafters makes; etc. There are contexts in which interlocutors do not have such characteristics. In such contexts, conflictual crafters grant that their views lack in rational persuasion and, so, may even intensify conflict by bringing more dissensus. This consequence, though, is very likely practically inevitable. Therefore, conflictual crafters embrace it. This is a third reason for calling this craft of theirs a conflictual craft.

\section{d. Neither Suspension of Judgment nor Universal Judgment but Particular Judgment}

Accordingly, the conflictual craft neither aims to bring about a suspension of judgement, nor purports to make universal judgments. Rather, this craft seeks to back up particular judgments, that is, deniable metaphysical claims, such as (i), (ii), (iii) and this essay's core thesis. Consider, then, that if Sextus were a conflictual crafter, he would rely on rationally deniable claims in seeking to avoid the stated alternative objection while justifying his own practices visà-vis those of tattooing babies, wearing brightly-coloured full-length dresses or having sex with women in public. Accordingly, when confronted with Alexander's troops, Pyrrho would have proceed in a similar manner, were him to be a conflictual crafter, that is, he would rely on at least one deniable metaphysical claim in imperfectly justifying a course of action. The same would have been done by the guard in the U.S./ Mexico border, were him a conflictual crafter as opposed to a skeptic. In doing so, he would accept the impossibility of not running into conflict with anyone, not even with others. Indeed, according to conflictual crafters, to live as a person is basically to live in 
conflict with such others. This is, then, a fourth reason for calling the craft supported here a conflictual craft.

\section{e. Neither Tranquility nor Fundamental Health but Singular Health}

Finally, the conflictual craft neither seeks the skeptic's tranquility nor the dogmatist's fundamental health. Indeed, given that persons have been inserted into all sorts of conflictual communities, I tend to think that it is impossible for them to actually fulfill these goals; it is simply "unrealistic" to even aim to do so. The reason is that persons who are inserted into conflictual communities are constantly running into theoretical and practical disputes, especially with others. Hence, it is quite hard to believe that anyone living in such communities could achieve the mind state of tranquility or express a fundamental health. Now note that this last considerably weak claim is to be distinguished from a much stronger claim: the claim that skeptics as well as dogmatists have always implicitly naively attempted to bring about a non-conflictual community in which there are no theoretical and practical disputes, and that no one is an other of anyone else.

I am not committed to this stronger claim, but I would like to state that I tend to agree with Forster when he speculates that Pyrrho might have had "at bottom a yearning for something from the past", that is, an Archaic non-conflictual Ancient Greek community. ${ }^{49}$ In fact, I also tend to think that a dogmatist also yearns for something similar: a future non-conflictual community in which all persons unanimously agreed with the dogmatist's views on disputes. I cannot back up these tendencies of mine in this essay, where I simply limit to use the imperfect justificatory

${ }^{49}$ Forster (2005: 70).

Manuscrito - Rev. Int. Fil. Campinas, v. 42, n. 2, pp. 47-83, Abr.-Jun. 2019. 
resource of stating that the existence of others appears to make the goal of bringing about a non-conflictual community hardly achievable. Indeed, the fifth and last reason for calling my craft a conflictual one is that $\mathrm{I}$, in a more (so to speak) "realist vein", do not aim to bring about a non-conflictual community into existence, but, rather, seek to achieve a goal that is more likely attainable than the skeptic and the dogmatic one for who anyone who is inserted into a conflictual community.

The goal I have in mind is that of bringing about at least in myself a singular health. By this, it is to be understood the health of thinking and acting with accordance with what properly characterizes myself in a way that currently strikes me as being persuasive and that may also be persuasive and helpful for other legitimate rational peers who are part of the conflictual communities I am inserted. To express this singular health, then, is what I hope to have done here, while spelling out reasons for (i), (ii) and (iii), and for the claim that one is to react to the fact that, since immemorial times, persons have been engaged in disputes by adopting the conflictual craft.

\section{REFERENCES}

BARnes, J. "The Beliefs of a Pyrrhonist" in Burnyeat and Frede (1997), 58-92.

BuenO, O. "Davidson and Skepticism: How not to Respond to the Skeptic", Principia 9, 2005.

"Is the Pyrrhonist an Internalist" in Machuca (2011), 179-192.

"Disagreeing with the Pyrrhonist" in Machuca (2013), 24-45.

"Carnap, Logicism, and Ontological

Manuscrito - Rev. Int. Fil. Campinas, v. 42, n. 2, pp. 47-83, Abr.-Jun. 2019. 
Commitment" in Costreie (2016), 205-236. and SMITH, P. J. "Skepticism in Latin America" in Zalta (2016), URL: https://plato.stanford.edu/archives/spr2016/entries /skepticism-latin-america/.

Burnyeat, M. F. "Can the Sceptic Live his Scepticism?" in Burnyeat (2012), 205-236.

\section{Explorations in Ancient and Modern}

Philosophy Vol. 1. Cambridge: Cambridge University Press, 2012. and FREDE, M. (eds.) (1997), The Original Sceptics: A Controversy, Cambridge: Hackett Publishing Company.

Costreie, S. (ed.) (2016), Early Analytic Philosophy: New Perspectives on the Tradition, Dordrecht: Springer.

Diogenes LAERTIUS. Lives of Eminent Philosophers.

Trans. Pamela Mensch. Oxford: Oxford University Press, 2018.

FINE, G. "Scepticism, Existence, and Belief: A Discussion of R.J. Hankinson, The Sceptics" in Taylor (1996), 273-290.

FOGELIN, R. J. Pyrrhonian Reflections on Knowledge and Justification, Oxford: Oxford University Press, 1994.

FORSTER, M. N. Hegel and Skepticism, Cambridge, Mass.: Harvard University Press, 1989. "Hegelian vs. Kantian Interpretations of Pyrrhonism: Revolution or Reaction?", Kritisches Jahrbuch der Philosophie Vol. 10, 53-70, 2005. Kant and Skepticism, New Jersey: Princeton University Press, 2008. 
FREDE, M. "The Sceptic's Beliefs" in Burnyeat and Frede (1997), 1-25.

Giovanni, G. D. (ed.) (2000), Between Kant and Hegel:

Texts in the Development of Post-Kantian Idealism, Cambridge: Hackett Publishing Company.

HEGEL, G.W.F. “On the Relationship of Skepticism to Philosophy, Exposition of its Different Modifications and Comparison of the Latest Form with the Ancient One". Trans. H.S. Harris. In Giovanni (2000), 311-363.

KLEIN, P. "How to be an Infinitist about Doxastic Justification”, Philosophical Studies 134.1, 25-29, 2007.

MaCHuCA, D. (ed.) (2011), New Essays on Ancient Pyrrhonism, Leiden: Brill. (2013), Disagreement and Skepticism, New York:

Routledge.

MoreirA, F.G.A. Por uma estética do constrangimento, Rio de Janeiro: Oito e Meio, 2013. “An Apology of Carnap”, Manuscrito 37 (2), 261-289, 2014.

"Overcoming Metametaphysics: Nietzsche and Carnap", Nietzsche-Studien, Volume 47, Issue 1, 240 271, 2018.

Disputes: The Incommensurable Greatness of Micro-Wars. University of Miami. PhD Dissertation. 2019. URL: https://scholarlyrepository.miami.edu/oa dissertatio ns/2284/.

"Deleuze's Left-Wing Approach to Metaphysics", Revue philosophique de la France et de l'étranger, forthcoming. 
Muniz, F. A Potência da Aparência: um estudo sobre o pražer e a sensação nos Diálogos de Platão, São Paulo: Editora Annablume, 2011.

Olaso, E. d. "La crisis pirrónica de Hume”, Revista Latinoamericana de Filosofía 3(2), 131-143, 1977. "Otra vez sobre el escepticismo de Hume", Manuscrito 1 (1), 65-82, 1978. "Los dos escepticismos del vicario saboyano", Manuscrito, 2(3), 7-23, 1980a. “Thomas Hobbes y la recta razón”, Manuscrito, 4(1), 29-35, 1980b.

"La investigación y la verdad", Manuscrito, 6(2), 4562, 1983. “Certeza y escepticismo" in Villoro (1999).

Porchat, O. Rumo ao Ceticismo, São Paulo: Editora Unesp, 2007.

Rowlands, M. Can Animals be Persons?, Oxford: Oxford University Press, 2019.

SEXTUS EMPIRICUS. Outlines of Scepticism. Trans. Julia Annas and Jonathan Barnes. Cambridge: Cambridge University Press, 2000.

Smith, P. J. Uma Visão Cética do Mundo: Porchat e a Filosofia, São Paulo: Editora Unesp, 2017.

TAYLOR, C.C.W. (ed.) (1996), Oxford Studies in Ancient Philosophy Vol 14, Oxford: Oxford University Press.

VILlORO, L. (ed.) (1999), El conocimiento (Enciclopedia Iberoamericana de Filosofía, Vol. 20), Madrid: TROTTA.

WhiTE, T. In Defense of Dolphins: The New Moral Frontier, Malden, Mass.: Blackwell, 2007. 
ZALTA, E. N. (ed.), The Stanford Encyclopedia of Philosophy, (2016), URL: https://plato.stanford.edu/.

$(\mathrm{cc}) \mathrm{BY}$

Manuscrito - Rev. Int. Fil. Campinas, v. 42, n. 2, pp. 47-83, Abr.-Jun. 2019. 